\title{
Assessment of metals behaviour in industrial soil using sequential extraction, multivariable analysis and a geostatistical approach
}

\author{
M Gabarrón *, A. Faz, S. Martínez-Martínez, R. Zornoza, J.A. Acosta \\ Sustainable Use, Management, and Reclamation of Soil and Water Research Group, Technical University of Cartagena, Paseo Alfonso XIII, 48, 30203 Cartagena, Murcia, Spain
}

\section{A R T I C L E I N F O}

\section{Article history:}

Received 1 April 2016

Revised 17 October 2016

Accepted 31 October 2016

Available online 02 November 2016

\section{Keywords:}

Chemical speciation

Heavy metals

Distribution maps

Soil pollution

\begin{abstract}
A B S T R A C T
The main objectives of this study were to evaluate the degree of $\mathrm{Pb}, \mathrm{Cu}, \mathrm{Zn}, \mathrm{Cd}, \mathrm{Cr}$ and Ni pollution using pollution indexes and geostatistical approach, and to assess metals dynamic using sequential extraction procedure and multivariable statistical analysis in surface soils and soil profiles from an industrial complex as a base for a correct management in order to avoid health and environmental problems. Results showed that the industrial activity increases both $\mathrm{Pb}\left(103 \mathrm{mg} \mathrm{kg}^{-1}\right), \mathrm{Zn}\left(526 \mathrm{mg} \mathrm{kg}^{-1}\right)$ and $\mathrm{Cu}\left(39 \mathrm{mg} \mathrm{kg}^{-1}\right)$ concentrations and salinity in soil. Pollution indexes showed that industrial soils were moderately contaminated by $\mathrm{Zn}, \mathrm{Pb}, \mathrm{Cu}, \mathrm{Cr}$ and $\mathrm{Ni}$ as well as a moderate ecological risk was reported. Two main areas were identified: southeast area with the highest metal concentrations, and northwest area with the lowest levels. Chemical speciation of metals showed that the residual phase was the dominant phase for all metals. However, $\mathrm{Pb}$ and $\mathrm{Zn}$ were highly associated to the reducible phase (25-30\% and 35-40\% respectively) and a significant concentration was associated to carbonates (5\% for both metals). In contrast, $\mathrm{Cu}, \mathrm{Cr}$ and Ni were mainly bound to the residual phase ( $>80 \%$ for all metals) with low concentrations retained to reducible phase, and very low concentrations bound to the most labile phases. Cd was the most mobile metal with high concentration associated to exchangeable (5\%) and carbonates (15$20 \%$ ) phases. Therefore, $\mathrm{Pb}, \mathrm{Zn}$ and $\mathrm{Cd}$ represent the greatest risk for human health and the environment.
\end{abstract}

(C) 2016 Published by Elsevier B.V.

\section{Introduction}

The development of industrialization has caused an increase of soil pollution by metals in the last decades, whose effects are not only limited to industrial soils but also affect to the adjacent lands, which is especially intense when soils are used for discharge poorly treated liquid effluents and disposal of solid waste as well as deposition of exhaust gas from the industries (Fakayode and Onianwa, 2002; Wu et al., 2011). However the persistence and distribution of metals in industrial areas is mainly affected by factors such as the nature of parental material, properties of soil or climatic condition (Krishna and Govil, 2008). Metals in soil can remain for a long period of time acting as source and sink of contamination (Acosta et al., 2015) and therefore they are potentially hazard to ecosystems and human health (Yaylali-Abanuz, 2011). Human exposure to metal pollutants may cause nervous, renal, cardiovascular and reproductive systems (Christoforidis and Stamatis, 2009). Therefore, in order to develop policies on pollution control and environmental management, as well as, to make decisions on soil remediation procedures, it is necessary to carefully evaluate the behaviour and distribution of metals in soils.

\footnotetext{
* Corresponding author.

E-mail address: maria.gabarron@upct.es (M. Gabarrón).
}

The contribution of metals to environmental pollution from industrial emissions has been the main subject of many studies in the recent years (Ordoñez et al., 2003; Al-Khashman and Shawabkeh, 2006; Sekhar et al., 2006; Govil et al., 2008; Krishna and Govil, 2008; Wu et al., 2011), where different indexes, such as contamination factor, enrichment factor or ecological risk index, have been used for determining the degree of soil pollution (Loska et al., 2004; Yaylali-abanuz, 2011; Yuan et al., 2014). However, although the total metal content in soil is useful to estimate the degree of soil pollution, the mobility of metal does not necessarily depend directly on its total metal content (Kumar et al., 2013). Chemical speciation is usually used to understand the geochemical processes governing metal mobilization (Yuan et al., 2004) because provide knowledge about the identification and quantification of different species, forms or phases of metals present in a material, such as soil, sediment or waste (Naji et al., 2010), and its availability on the environment.

In addition, the identification of pollution sources, the risk areas, and the evaluation of metals behaviour in soil have been identified as key points to reach effective soil reclamations (Chen et al., 2009; Acosta et al., 2011). The use of multivariate statistical analysis combined with geostatistical techniques have been successfully applied in the identification of sources, evaluation of metal behaviour in soil and mapping of metal spatial distribution (Rodríguez-Martín et al., 2006; Saby et al., 2009; Maas et al., 2010; Lu et al., 2012; Li et al., 2013b; Shao et al., 2014), being useful tools for developing future reclamation plans in 
industrial areas and its surrounding. However, the use of advanced analytical and statistical methods combined with spatial distribution analysis for evaluating the risk posed at the specific site has been little studied.

The main objective of this study was to demonstrate that the combination of different techniques and methods (sequential extraction procedure, multivariable statistical analysis and geostatistical approach) is a powerful tool for an integral evaluation of the environmental risk in areas affected by metals. To reach this objective, the degree of metals pollution $(\mathrm{Pb}, \mathrm{Cu}, \mathrm{Zn}, \mathrm{Cd}, \mathrm{Cr}$ and $\mathrm{Ni}$ ) and the delimitation of risk areas using pollution indexes and a geostatistical approach were carried out. Otherwise, the identification of sources of metals and their behaviour were evaluated using a sequential extraction procedure and a multivariable statistical analysis.

\section{Material and methods}

\subsection{Study area and sampling}

In order to evaluate the combination of analytical, statistical and geostatistical techniques for assessing contaminated sites, the most important industrial complex of Murcia city was selected (southeast of Spain), which is located in the southwest of the city. About 841 companies are situated in this industrial area, such as manufacturing paints, steel product, chemicals, electrical materials, etc. The climate of the area is semiarid Mediterranean with an annual average temperature of $18{ }^{\circ} \mathrm{C}$ and annual precipitation of $350 \mathrm{~mm}$. The geology of the area is dominated by Quaternary alluvial deposits from the Segura and Guadalentín rivers (IGME, 1976). In the last decades, the soils where the industrial area is currently located were subjected to intense agricultural cultivation of lemon, oranges, cereals and vegetables. Currently, the industrial soil is classified as Calcaric regosol (W.R.B., 2014), characterized by low differentiation among horizons, a low organic matter content and high carbonates content. The study area also includes a natural area, without any influence of the industrial activities and with the same geological material. According with W.R.B. (2014) the natural soil is classified as Haplic calcisol, characterized by the presence of calcic horizon, with low organic matter content. This area was used as control site to determine the pollution degree of the industrial soils.

The industrial area has a surface of $3 \mathrm{~km}^{2}$ where 10 surface soil samples $(0-5 \mathrm{~cm})$ were collected (Fig. 1$)$. In addition, another 10 soil samples from the natural area were also sampled. At each sampling point, three sub-samples were collected $1 \mathrm{~m}$ apart from the vertices of a triangle to form a composite sample. Soil samples were taken using a soil spade. Two soil profiles were identified in the north-west and southeast of the industrial area corresponding to low and high pollution respectively (Fig. 1); four samples were collected from different depths $(0-5 \mathrm{~cm}, 5-10 \mathrm{~cm}, 10-15 \mathrm{~cm}$ and $15-30 \mathrm{~cm})$. All samples were taken

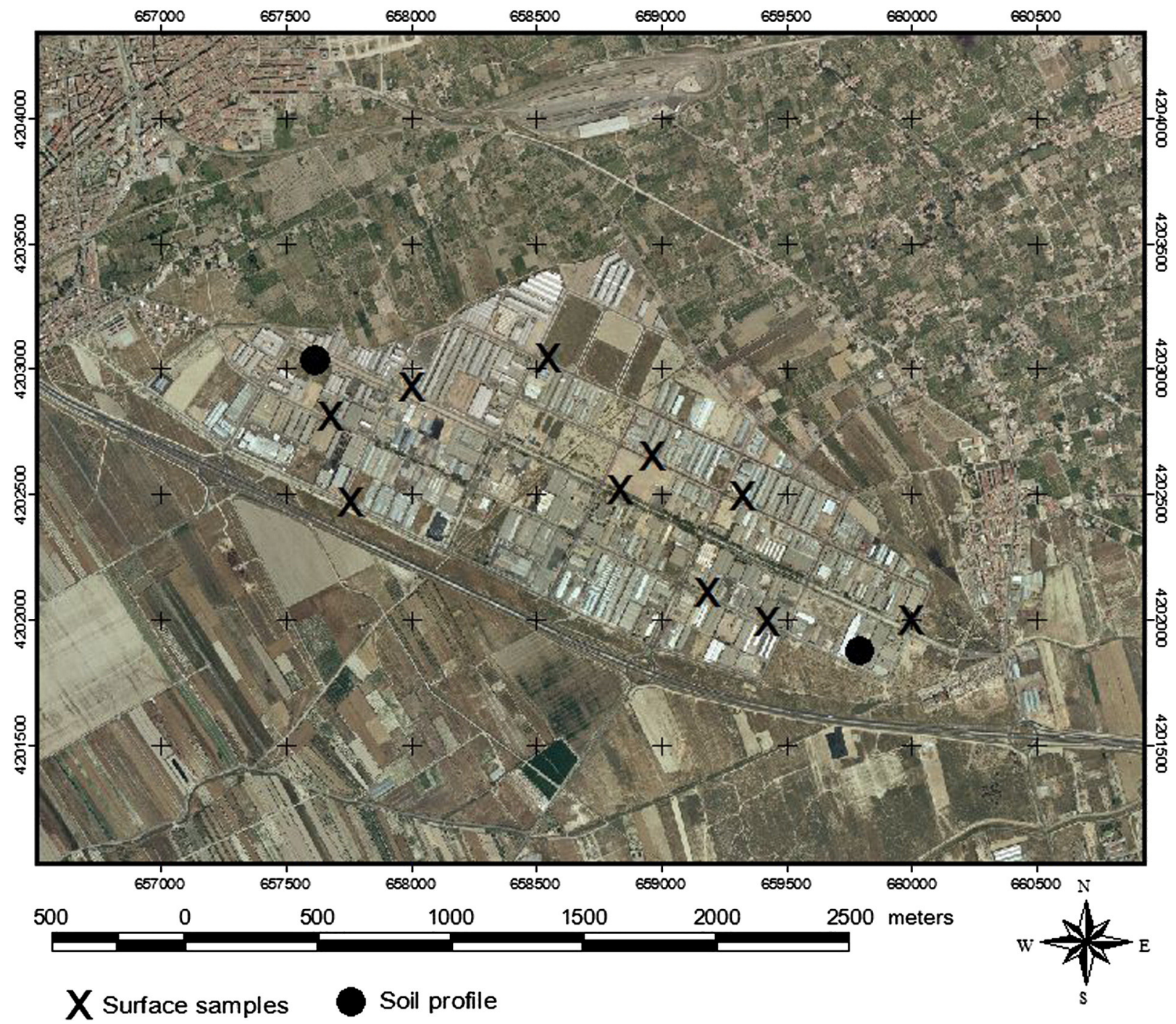

Fig. 1. Sampling location. 
to the laboratory, and then they were air dried at room temperature during $72 \mathrm{~h}$ and sieved to $<2 \mathrm{~mm}$ prior to physicochemical analyses.

\subsection{Analytical methods}

The following properties were analysed: soil organic carbon (OC) contents by the dichromate method (Soil Survey Staff, 2004); soil pH in $\mathrm{H}_{2} \mathrm{O}$ using a glass electrode in a $1: 1$ soil/water suspension (Soil Survey Staff, 2004); electrical conductivity (EC) in a 1:5 soil/water suspension (Andrades, 1996); equivalent calcium carbonate by the volumetric method using Bernard's calcimeter, and cation exchange capacity (CEC) using sodium chloride and ammonium acetate (Soil Survey Staff, 2004).

For total metal content, $1 \mathrm{~g}$ of ground sample was digested in $10 \mathrm{~mL}$ nitric acid and $10 \mathrm{~mL}$ perchloric acid at $210{ }^{\circ} \mathrm{C}$ during $90 \mathrm{~min}$. After cooling, $0.1 \mathrm{~N} \mathrm{HCl}$ was added to fill a $100 \mathrm{~mL}$ volumetric flask (Risser and Baker, 1990). For soil extractable metals, DTPA (diethylene triamine pentaacetic) was used (Linsay and Norvell, 1978). Water soluble metals were determined according to Ernst (1996). Total, DTPA extractable and water soluble metals $(\mathrm{Pb}, \mathrm{Cu}, \mathrm{Zn}, \mathrm{Cd}, \mathrm{Cr}, \mathrm{Co}$ and $\mathrm{Ni}$ ) were measured by atomic absorption spectrometry (AAS).

Sequential extraction procedure by Tessier et al. (1979), modified by Li et al. (1995), was used for the identification of the main binding sites, the strength of metal binding to particulates and the phase associations of metals in soils (Rauret, 1998). This provides information of mobility, bioavailability and toxicity of metals bound to different soil phases. The extraction was carried out in order to obtain the following fractions: 1 : exchangeable; 2 : carbonate bound and specifically adsorbed; 3: bound to Fe-Mn-oxides: 4: bound to organic matter and sulfide and 5: residual.

Certified reference material (BAM-U110) from the Federal Institute for Materials Research and Testing (F.I.M.R.T., 2010) and reagent blanks were used as quality control samples during the analyses. We obtained recoveries (the sum of the five fractions from sequential extraction analysis to the total element concentration of BAM-U110) of 92-109\% for $\mathrm{Cd}, 91-98 \%$ for $\mathrm{Cu}, 94-105 \%$ for $\mathrm{Pb}, 91-99 \%$ for $\mathrm{Zn}, 92-107 \%$ for $\mathrm{Cr}$ and $96-108 \%$ for $\mathrm{Ni}$.

\subsection{Enrichment factor}

Enrichment factor (EF) was calculated using the modified formula (1) from Loska et al. (2004). The EF is based on the standardization of a tested element against a reference one. In this study cobalt was used as reference element due to its low occurrence. The reference environment adopted was the average concentration of elements in the natural area.

$\mathrm{EF}=\left(\mathrm{C}_{\mathrm{n}}(\right.$ sample $) / \mathrm{C}_{\mathrm{ref}}($ sample $\left.)\right) /\left(\mathrm{B}_{\mathrm{n}}(\right.$ background $) / \mathrm{B}_{\text {ref }}($ background $\left.)\right)$

where $C_{n}$ (sample) is the content of the examined element in the industrial soils, $C_{\text {ref }}$ (sample) is the content of the reference element in the industrial soils, $B_{n}$ (background) is the content of examined element in the natural soils and $B_{\text {ref }}$ (background) is the content of the reference element in the natural soils. According with Saeedi et al. (2012), EF was divided into five groups: $\mathrm{EF}<2$ : deficiency to minimal enrichment; $2 \leq \mathrm{EF}<5$ : moderate enrichment; $5 \leq \mathrm{EF}<20$ : significant enrichment; $20 \leq \mathrm{EF}<40$ : very high enrichment; $\mathrm{EF} \geq 40$ : extremely high enrichment.

\subsection{Concentration factor}

Concentration factors $(\mathrm{CF})$ were calculated as the ratio of the content of a given metal $\left(C_{\text {metal }}\right)$ to the background value ( $\left.C_{\text {background }}\right)$ :

$\mathrm{CF}=\mathrm{C}_{\text {metal }} / \mathrm{C}_{\text {background }}$
The background concentration adopted was the average concentration of elements in the natural area. According to Buhiyan et al. (2010) and Varol (2011), CF was divided into six groups: $\mathrm{CF} \leq 0$ : non contaminated, $0<\mathrm{CF} \leq 1$ : slightly contaminated; $1<\mathrm{CF} \leq 3$ : moderately contaminated; $3<\mathrm{CF} \leq 5$ : considerately contaminated; $5<\mathrm{CF} \leq 6$ : strongly contaminated; $\mathrm{CF}>6$ : very strongly contaminated.

\subsection{Ecological risk}

This index comprises a single contamination coefficient, a comprehensive contamination measure, the toxic response factor for each metal, and a potential ecological risk index. The specific formulas are:

The single contamination coefficient : $C_{\mathrm{fi}}=\mathrm{C}_{\mathrm{i}} / \mathrm{C}_{\mathrm{b}}$

where $C_{\mathrm{fi}}$ is the contamination coefficient of a particular metal, $\mathrm{C}$ is the measured data of soil metals, and $C_{b}$ is the background value.

The comprehensive contamination measure : $\mathrm{E}_{\mathrm{i}}=\mathrm{C}_{\mathrm{fi}} \times \mathrm{T}_{\mathrm{i}}$

where $T_{i}$ is the toxic response factor. According to Hakanson (1980) the toxicity values $\left(\mathrm{T}_{\mathrm{i}}\right.$ ) are: $\mathrm{Pb}, \mathrm{Ni}$ and $\mathrm{Cu}(5), \mathrm{Cd}(30), \mathrm{Cr}(2), \mathrm{Zn}(1)$ and $\mathrm{Ni}$ (5).

The potential ecological risk index is : $\mathrm{RI}=\Sigma \mathrm{E}_{\mathrm{i}}$

According to Sun et al. (2010), CF was divided into four groups: $\mathrm{RI} \leq 50$ low risk; $50 \leq \mathrm{RI}<100$ moderate risk; $100 \leq \mathrm{RI} \leq 200$ considerable risk and $\mathrm{RI}>200$ very strong risk.

\subsection{Statistical treatment and spatial distribution of metals}

The fitting of the data to a normal distribution for all properties and metal concentrations was checked with the Kolmogorov-Smirnov test at $\mathrm{P}<0.05$. We carried out a one-way ANOVA to investigate the differences among industrial and natural soils. Principal Component Analysis (PCA) was used to study the relationships among metals fractions and physicochemical properties and their grouping into a few factors. Varimax rotation was applied because it minimizes the number of variables with a high loading on each component and facilitates the interpretation of results (Micó et al., 2006). These analyses were carried out using SPSS 19.0 for Windows (Norusis, 1993).

The total concentrations of metals were used as the input data to produce distribution maps using Arcview 3.1. An Inverse Distanced Weighted (IDW) method was adopted to generate the distribution maps (Burrough and McDonnell, 1998; Lee et al., 2006).

\section{Results and discussion}

\subsection{Geochemical characterization of soil}

Geochemical characterization is essential to evaluate the environmental risk by metals in soil, since the processes and mechanisms involved on metals behaviour are affected by soil constituents and its properties (Acosta et al., 2011; Xiao et al., 2015). In this study, soils were slightly alkaline, with high amount of carbonates and moderate levels of $\mathrm{OC}$, with no significant differences for $\mathrm{pH}, \mathrm{OC}$ and carbonate contents between industrial and natural areas (Table 1), therefore it is expected a low metals mobility. Similar OC content in both areas is due to the former land use of the industrial soils where the application of organic fertilizers took place for crop production. In contrast, electrical conductivity was higher in the industrial soils than natural areas, which indicated that industrial activities increase soil salinity through spill or dump of industrial waste.

In addition, the comparison of the metals concentrations between affected areas by human activities and naturals areas can be used to identify potential sources. Concentrations of total and DTPA extractable 
Table 1

Geochemical characterization of soil surface samples.

\begin{tabular}{|c|c|c|c|c|c|c|c|c|}
\hline & \multicolumn{4}{|c|}{ Industrial area } & \multicolumn{4}{|c|}{ Natural area } \\
\hline & Mean & Stand. dev. ${ }^{\mathrm{a}}$ & Minimum & Maximum & Mean & Stand. dev. ${ }^{\mathrm{a}}$ & Minimum & Maximum \\
\hline $\mathrm{pH}$ & 8.0 & 0.2 & 7.8 & 8.3 & 8.4 & 0.3 & 8.2 & 9.2 \\
\hline E.C. $\left(\mathrm{dS} \mathrm{m} \mathrm{m}^{-1}\right)^{\mathrm{a}}$ & $0.4 a^{b}$ & 0.3 & 0.1 & 1.3 & $0.1 b$ & 0.0 & 0.1 & 0.1 \\
\hline Carbonates (\%) & 37 & 5.7 & 28 & 45 & 39 & 2.8 & 36 & 46 \\
\hline Organic carbon (\%) & 1.7 & 0.8 & 0.6 & 3.0 & 1.3 & 0.3 & 1.1 & 1.8 \\
\hline Total $\mathrm{Pb}\left(\mathrm{mg} \mathrm{kg}^{-1}\right)$ & $85 a$ & 11 & 71 & 103 & $67 b$ & 4.4 & 57 & 71 \\
\hline Total $\mathrm{Zn}\left(\mathrm{mg} \mathrm{kg}^{-1}\right)$ & $176 a$ & 167 & 53 & 526 & $34 b$ & 6.2 & 25 & 43 \\
\hline Total $\mathrm{Cu}\left(\mathrm{mg} \mathrm{kg}^{-1}\right)$ & $39 a$ & 39 & 19 & 149 & $29 b$ & 3.6 & 22 & 35 \\
\hline Total Cd $\left(\mathrm{mg} \mathrm{kg}^{-1}\right)$ & $1.2 \mathrm{~b}$ & 0.4 & 0.3 & 1.7 & $1.8 \mathrm{a}$ & 0.6 & 0.6 & 2.5 \\
\hline Total $\mathrm{Cr}\left(\mathrm{mg} \mathrm{kg}^{-1}\right)$ & $43 a$ & 20 & 25 & 96 & $30 \mathrm{~b}$ & 9.7 & 18 & 47 \\
\hline Total Ni $\left(\mathrm{mg} \mathrm{kg}^{-1}\right)$ & $66 a$ & 46 & 46 & 196 & $24 b$ & 1.3 & 22 & 27 \\
\hline DTPA extr. ${ }^{a} \mathrm{~Pb}\left(\mathrm{mg} \mathrm{kg}^{-1}\right)$ & 3.9a & 2.0 & 1.25 & 6.8 & $0.42 \mathrm{~b}$ & 0.12 & 0.28 & 0.67 \\
\hline DTPA extr. Zn (mg kg-1) & $30 a$ & 60 & 0.76 & 187 & $2.11 \mathrm{~b}$ & 0.30 & 1.50 & 2.59 \\
\hline DTPA extr. $\mathrm{Cu}\left(\mathrm{mg} \mathrm{kg}^{-1}\right)$ & $3.5 \mathrm{a}$ & 3.7 & 0.77 & 13 & $1.33 \mathrm{~b}$ & 0.06 & 1.22 & 1.40 \\
\hline DTPA extr. Cd (mg kg $\left.{ }^{-1}\right)$ & $0.05 b$ & 0.03 & 0.00 & 0.09 & $0.08 \mathrm{a}$ & 0.04 & 0.01 & 0.12 \\
\hline DTPA extr. $\mathrm{Cr}\left(\mathrm{mg} \mathrm{kg}^{-1}\right)$ & $0.29 \mathrm{a}$ & 0.10 & 0.08 & 0.45 & $0.19 \mathrm{~b}$ & 0.05 & 0.13 & 0.29 \\
\hline DTPA extr. Ni (mg kg-1) & $0.78 \mathrm{a}$ & 0.16 & 0.63 & 1.16 & $0.29 b$ & 0.07 & 0.20 & 0.45 \\
\hline Water sol. ${ }^{\mathrm{a}} \mathrm{Pb}\left(\mathrm{mg} \mathrm{kg}^{-1}\right)$ & $\mathrm{BDL}^{\mathrm{c}}$ & - & - & - & 0.13 & 0.03 & 0.09 & 0.19 \\
\hline Water sol. Zn ( $\left.\mathrm{mg} \mathrm{kg}^{-1}\right)$ & $0.58 \mathrm{a}$ & 0.62 & 0.00 & 1.89 & $0.10 \mathrm{~b}$ & 0.03 & 0.05 & 0.15 \\
\hline Water sol. $\mathrm{Cu}\left(\mathrm{mg} \mathrm{kg}^{-1}\right)$ & $0.17 \mathrm{~b}$ & 0.11 & 0.08 & 0.42 & $0.33 \mathrm{a}$ & 0.12 & 0.11 & 0.46 \\
\hline Water sol. $\mathrm{Cd}\left(\mathrm{mg} \mathrm{kg}^{-1}\right)$ & $0.01 b$ & 0.01 & 0.00 & 0.02 & $0.06 a$ & 0.03 & 0.01 & 0.09 \\
\hline Water sol. $\mathrm{Cr}\left(\mathrm{mg} \mathrm{kg}^{-1}\right)$ & $0.20 \mathrm{a}$ & 0.10 & 0.08 & 0.37 & $0.10 \mathrm{~b}$ & 0.03 & 0.06 & 0.15 \\
\hline Water sol. $\mathrm{Ni}\left(\mathrm{mg} \mathrm{kg}^{-1}\right)$ & $0.44 \mathrm{a}$ & 0.13 & 0.26 & 0.65 & $0.09 \mathrm{~b}$ & 0.04 & 0.04 & 0.17 \\
\hline
\end{tabular}

a E.C.: electrical conductivity; extr.: extractable; sol.: soluble; stand. dev.: standard deviation.

b Means followed by different letters are significantly different $(\mathrm{P}<0.05)$.

BDL: below detection limit.

metals, except for $\mathrm{Cd}$, were higher in industrial soils than in natural soils, showing the influence of industrial activities on metals accumulation in soils. This trend for $\mathrm{Pb}$ suggests the influence of traffic as main source of this metal, where $\mathrm{Pb}$ can be released from brake, tyres and exhaust fumes. Our results are consistent with other studies where the highest $\mathrm{Pb}$ concentrations occurred in areas near to industrial activities and main highways and roads (Han et al., 2009; Aelion et al., 2009).

The high variability of $\mathrm{Zn}$ concentrations (53-526 $\mathrm{mg} \mathrm{kg}^{-1}$ ) in the industrial soils indicated that this metal came from a variability of industrial activities, due to the presence of many types of factories in this area (e.g., metals recycling, steel products, plastic plants, electrical materials, etc.). Although the highest concentration of $\mathrm{Zn}$ reached was $526 \mathrm{mg} \mathrm{kg}^{-1}$, the mean value (176 $\mathrm{mg} \mathrm{kg}^{-1}$ ) was lower than those reported by Fakayode and Onianwa (2002) and Abollino et al. (2002), in industrial areas where the main activities were the production of plastic materials, paints and pharmaceutical products, 282 and $361 \mathrm{mg} \mathrm{kg}^{-1}$, respectively.

Mean concentration of $\mathrm{Cu}$ in the industrial area was low (39 $\mathrm{mg} \mathrm{kg}^{-1}$ ), although higher than the concentration found in the natural area. This value was lower than those reported in other industrial sites (Ravera et al., 2006; Pen-Mouratov et al., 2008), which suggests a low industrial influences on soil $\mathrm{Cu}$ concentrations.

Mean $\mathrm{Ni}$ and $\mathrm{Cr}$ concentrations in industrial soils were higher than in natural soils, but lower than those reported in other industrial areas (Jean et al., 2007; McNear et al., 2007). So, the concentrations of these metals are likely associated to the geological material, and came from the materials used in the construction of this industrial complex, and not from the industrial activities themselves.

The DTPA extractable concentrations of $\mathrm{Pb}, \mathrm{Zn}, \mathrm{Cu}, \mathrm{Cr}$ and Ni were higher in industrial soils (Table 1 ). Therefore, high concentrations of these metals can be absorbed by plants causing a potential risk for the food chain (Pastor et al., 2007). Among all metals, Zn showed the highest water soluble fraction. With regard to $\mathrm{Pb}$, despite the high total and DTPA extractable concentration, the soluble fraction was below the detection limit. This highlights the low solubility of this metal, also reported by other authors (Burgos et al., 2006), and indicates that $\mathrm{Pb}$ is not highly mobilized in the environment.

\subsection{Soil pollution and spatial distribution of metals}

In order to determine de degree of pollution in contaminated soils, concentration factors (CF), enrichment factors (EF) and ecological risk indices (ERI) has been widely used (Zhang et al., 2009; Guillén et al., 2012; Saeedi et al., 2012; Lu et al., 2014; Yuan et al., 2014; Lin et al., 2016) and they were calculated in this study (Table 2). Results showed that industrial soils had high concentrations of $\mathrm{Pb}$ and $\mathrm{Zn}$, followed by $\mathrm{Cr}$, Ni and $\mathrm{Cu}$ exceeding the limits proposed by Varol (2011) for considering a moderately contaminated soil $(1<\mathrm{CF}<3)$. Some samples of the industrial soil was classified as very strongly contaminated by $\mathrm{Zn}$ ( $\mathrm{CF}=$ 7.8). Mean values obtained from the enrichment factors showed that industrial soils were moderately enriched by $\mathrm{Zn}(2<\mathrm{EF}<5)$ (Saeedi et al., 2012). However, some samples exceeded this value for $\mathrm{Pb}, \mathrm{Cu}, \mathrm{Cr}$ and $\mathrm{Ni}$. The highest EF value for industrial soil was classified as significantly enriched by $\mathrm{Zn}(\mathrm{EF}=5.98)$. Results obtained from ERI showed that industrial soils exceeded the values proposed by Sun et al. (2010) to consider a moderate risk $(50 \leq R I<100)$, with the highest values near to 90 .

According to these results some remediation actions should be carried out in order to reduce the risk for human health and the environment. However, the selection of the best available technology for soil remediation must be based on an exhaustive knowledge on metals behaviour. In addition, the only use of these indices is not enough to develop the remediation plans or monitoring strategies since it is necessary to identify the main impacted areas to focus the major and more intense actions. In this way, spatial distribution maps are useful to visualize the spatial pattern of metals in soils (Li et al., 2013a). These maps must be used to identify metal-enriched areas for applying the remediation strategies or the placement of stations for monitoring metals concentrations. Based on the spatial distribution of $\mathrm{Zn}$ and $\mathrm{Cd}$ concentrations (Fig. 2a and c), the study area can be divided into two zones: i) southeast, with the highest $\mathrm{Zn}$ and $\mathrm{Cd}$ concentrations, located in the main entrance to the industrial complex with high traffic density take place; and ii) northwest, with moderate levels of $\mathrm{Zn}$ and $\mathrm{Cd}$. Some authors have reported that high levels of $\mathrm{Cd}$ come from atmospheric deposition from highways or main roads in urban and industrial areas (Manta et al., 2002; Imperato et al., 2003). 
Table 2

Concentration, enrichment and ecological risk indexes from industrial soils.

\begin{tabular}{|c|c|c|c|c|c|c|c|c|c|}
\hline & \multicolumn{3}{|c|}{ Concentration factor } & \multicolumn{3}{|c|}{ Enrichment factor } & \multicolumn{3}{|c|}{ Ecological risk } \\
\hline & Mean & Minimum & Maximum & Mean & Minimum & Maximum & Mean & Minimum & Maximum \\
\hline Lead & 2.47 & 2.05 & 2.98 & 1.98 & 1.52 & 2.63 & 52 & 29 & 88 \\
\hline Zinc & 2.63 & 0.79 & 7.85 & 2.10 & 0.61 & 5.98 & & & \\
\hline Copper & 1.35 & 0.68 & 5.17 & 1.07 & 0.52 & 3.94 & & & \\
\hline Cadmium & 0.69 & 0.16 & 0.96 & 0.54 & 0.14 & 0.73 & & & \\
\hline Chromium & 1.44 & 0.82 & 3.21 & 1.12 & 0.63 & 2.07 & & & \\
\hline Nickel & 1.42 & 0.99 & 4.21 & 1.08 & 0.78 & 2.72 & & & \\
\hline
\end{tabular}

The spatial distribution map of $\mathrm{Pb}$ (Fig. 2b) showed that the higher concentrations were located in the southern section of the study area with a narrower range than the previous metals; therefore, the differences between north and south are not so evident
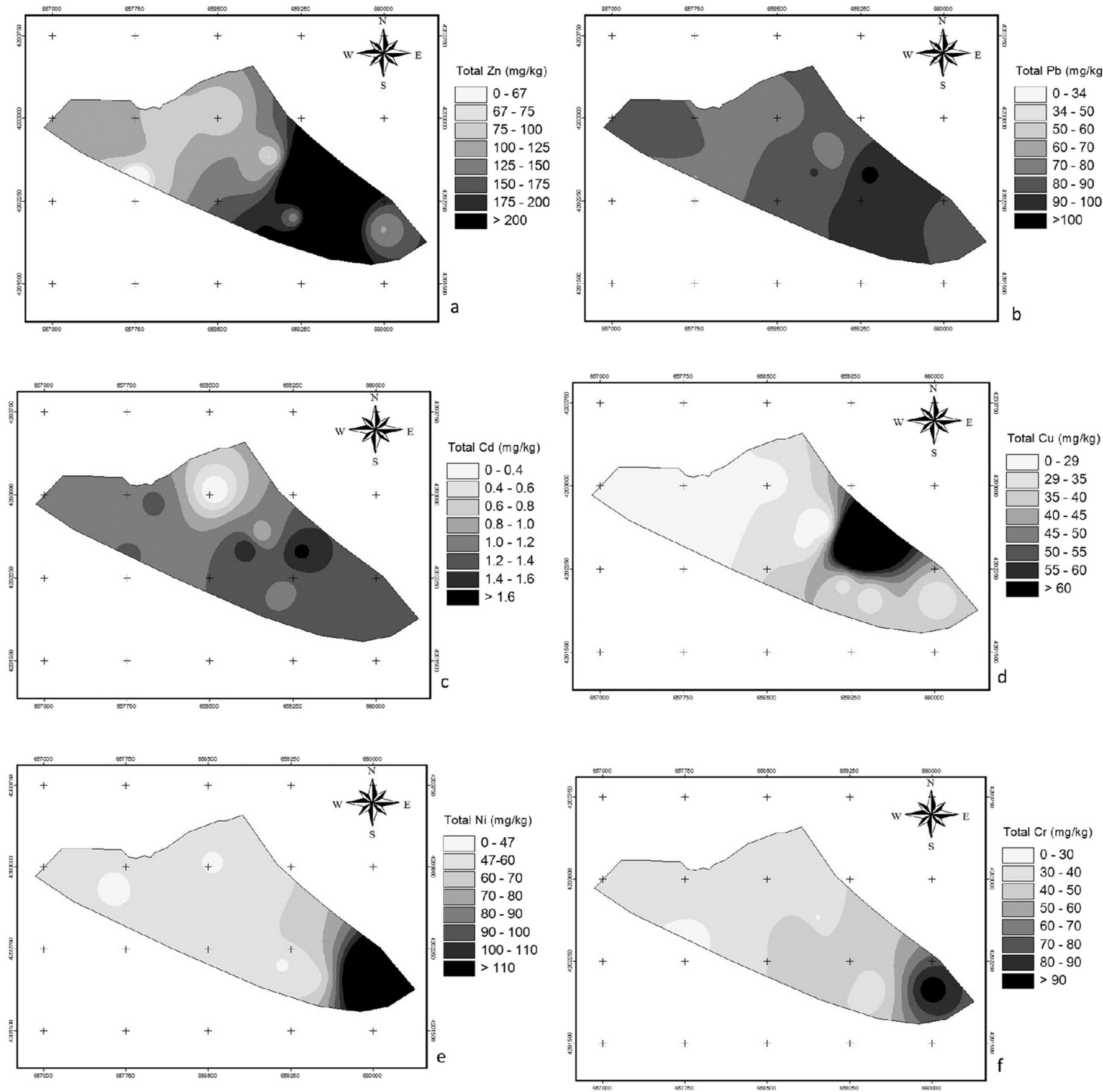

Fig. 2. Spatial distribution of total metals in the industrial area. 
Table 3

Geochemical characterization of soil profiles.

\begin{tabular}{|c|c|c|c|c|c|c|c|c|}
\hline & \multicolumn{4}{|c|}{ North-West (industrial area) } & \multicolumn{4}{|c|}{ South-West (Industrial area) } \\
\hline & $0-1 \mathrm{~cm}$ & $1-5 \mathrm{~cm}$ & $5-15 \mathrm{~cm}$ & $15-30 \mathrm{~cm}$ & $0-1 \mathrm{~cm}$ & $1-5 \mathrm{~cm}$ & $5-15 \mathrm{~cm}$ & $15-30 \mathrm{~cm}$ \\
\hline $\mathrm{pH}$ & 7.6 & 8.0 & 7.7 & 7.8 & 7.9 & 7.6 & 7.7 & 7.8 \\
\hline E.C. ${ }^{\mathrm{a}}\left(\mathrm{dS} \mathrm{m} \mathrm{m}^{-1}\right)$ & 2.4 & 1.6 & 1.8 & 2.0 & 2.5 & 2.1 & 3.0 & 3.5 \\
\hline Carbonates (\%) & 47 & 49 & 46 & 48 & 44 & 43 & 41 & 35 \\
\hline Organic carbon (\%) & 1.9 & 1.1 & 0.7 & 0.6 & 0.9 & 0.8 & 0.6 & 0.5 \\
\hline C.E.C. ${ }^{\mathrm{a}}\left(\mathrm{cmol} \mathrm{kg}^{-1}\right)$ & 20 & 13 & 9.7 & 7.6 & 9.7 & 9.8 & 8.3 & 7.8 \\
\hline Total $\mathrm{Pb}\left(\mathrm{mg} \mathrm{kg}^{-1}\right)$ & 22 & 24 & 21 & 20 & 214 & 183 & 107 & 79 \\
\hline Total Zn ( $\left.\mathrm{mg} \mathrm{kg}^{-1}\right)$ & 68 & 61 & 56 & 56 & 173 & 114 & 111 & 90 \\
\hline Total $\mathrm{Cu}\left(\mathrm{mg} \mathrm{kg}^{-1}\right)$ & 24 & 23 & 21 & 27 & 34 & 47 & 48 & 47 \\
\hline Total Cd ( $\left.\mathrm{mg} \mathrm{kg}^{-1}\right)$ & 1.7 & 1.3 & 1.2 & 1.1 & 1.5 & 1.3 & 1.8 & 1.4 \\
\hline Total $\mathrm{Cr}\left(\mathrm{mg} \mathrm{kg}^{-1}\right)$ & 45 & 49 & 50 & 48 & 63 & 65 & 54 & 61 \\
\hline Total Ni $\left(\mathrm{mg} \mathrm{kg}^{-1}\right)$ & 28 & 23 & 23 & 24 & 48 & 46 & 32 & 29 \\
\hline DTPA extr. ${ }^{a} \mathrm{~Pb}\left(\mathrm{mg} \mathrm{kg}^{-1}\right)$ & 0.4 & 0.6 & 0.5 & 0.5 & 1.0 & 1.3 & 1.4 & 1.3 \\
\hline DTPA extr. Zn ( $\left.\mathrm{mg} \mathrm{kg}^{-1}\right)$ & 1.1 & 0.8 & 0.6 & 0.6 & 2.1 & 2.3 & 1.6 & 1.7 \\
\hline DTPA extr. $\mathrm{Cu}\left(\mathrm{mg} \mathrm{kg}^{-1}\right)$ & 0.4 & 0.6 & 0.4 & 0.4 & 0.4 & 0.4 & 0.5 & 0.5 \\
\hline DTPA extr. Cd (mg kg $\left.{ }^{-1}\right)$ & 0.0 & 0.0 & 0.0 & 0.0 & 0.0 & 0.0 & 0.0 & 0.0 \\
\hline DTPA extr. $\mathrm{Cr}\left(\mathrm{mg} \mathrm{kg}^{-1}\right)$ & 0.3 & 0.3 & 0.2 & 0.2 & 0.4 & 0.3 & 0.2 & 0.2 \\
\hline DTPA extr. Ni ( $\left.\mathrm{mg} \mathrm{kg}^{-1}\right)$ & 0.0 & 0.0 & 0.0 & 0.0 & 0.0 & 0.0 & 0.0 & 0.0 \\
\hline
\end{tabular}

${ }^{a}$ E.C.: electrical conductivity; C.E.C.: cation exchange capacity; extr.: extractable.

Fig. 2d shows the spatial distribution of $\mathrm{Cu}$. The highest $\mathrm{Cu}$ concentration occurred in an isolated spot, likely associated to a discharge point of industrial waste. In general, as observed in the previous metals, the southeast area showed higher $\mathrm{Cu}$ concentrations than the northwest area.
The distribution of Ni and $\mathrm{Cr}$ concentrations (Fig. 2e and f) showed that there was a discordant area with a very high concentration in the southeast, corresponding to the main road and the main entrance of the industrial complex. However, since $\mathrm{Ni}$ and $\mathrm{Cr}$ concentrations in the rest of the area

Table 4

Concentration of metal $\left(\mathrm{mg} \mathrm{kg}^{-1}\right)$ from sequential extraction procedure.

\begin{tabular}{|c|c|c|c|c|c|c|c|c|c|}
\hline \multirow[t]{2}{*}{ Metal } & \multirow[t]{2}{*}{ Fraction } & \multicolumn{4}{|c|}{ North-West of the industrial area } & \multicolumn{4}{|c|}{ South-West of the industrial area } \\
\hline & & $0-1 \mathrm{~cm}$ & $1-5 \mathrm{~cm}$ & $5-15 \mathrm{~cm}$ & $15-30 \mathrm{~cm}$ & $0-1 \mathrm{~cm}$ & $1-5 \mathrm{~cm}$ & $5-15 \mathrm{~cm}$ & $15-30 \mathrm{~cm}$ \\
\hline \multirow[t]{7}{*}{$\mathrm{Pb}$} & Exchangeable & 0.2 & 0.2 & 0.2 & 0.2 & 0.1 & 0.1 & 0.1 & 0.1 \\
\hline & Carbonate & 0.3 & 0.2 & 0.3 & 0.2 & 9.5 & 7.8 & 7.4 & 5.3 \\
\hline & Reducible & 8.2 & 7.1 & 7.1 & 6.4 & 102 & 104 & 50 & 31 \\
\hline & Oxidizable & 0.1 & 0.1 & 0.1 & 0.1 & 0.9 & 0.8 & 0.7 & 0.2 \\
\hline & Residual & 14 & 13 & 15 & 12 & 100 & 74 & 70 & 40 \\
\hline & Sum & 23 & 20 & 23 & 19 & 213 & 187 & 129 & 76 \\
\hline & $\%$ recovery & 105 & 84 & 108 & 98 & 100 & 102 & 120 & 97 \\
\hline \multirow[t]{7}{*}{$\mathrm{Zn}$} & Exchangeable & 0.1 & 0.1 & 0.1 & 0.1 & 2.0 & 1.6 & 0.2 & 0.2 \\
\hline & Carbonate & 1.0 & 1.6 & 0.9 & 0.6 & 13 & 10 & 5.6 & 2.7 \\
\hline & Reducible & 18 & 13 & 14 & 15 & 29 & 37 & 27 & 34 \\
\hline & Oxidizable & 0.3 & 0.2 & 0.2 & 0.6 & 1.9 & 1.6 & 1.5 & 1.5 \\
\hline & Residual & 51 & 54 & 50 & 45 & 138 & 81 & 74 & 56 \\
\hline & Sum & 70 & 69 & 65 & 61 & 184 & 132 & 108 & 94 \\
\hline & $\%$ recovery & 102 & 113 & 115 & 109 & 106 & 116 & 96 & 104 \\
\hline \multirow[t]{7}{*}{$\mathrm{Cu}$} & Exchangeable & 0.3 & 0.2 & 0.2 & 0.1 & 0.2 & 0.3 & 0.2 & 0.2 \\
\hline & Carbonate & 0.1 & 0.2 & 0.1 & 0.1 & 0.2 & 0.3 & 0.5 & 0.6 \\
\hline & Reducible & 1.0 & 1.3 & 1.8 & 1.7 & 3.0 & 3.5 & 4.5 & 6.5 \\
\hline & Oxidizable & 0.5 & 0.3 & 0.3 & 0.3 & 0.6 & 0.7 & 1.1 & 1.4 \\
\hline & Residual & 23 & 23 & 27 & 23 & 31 & 37 & 39 & 38 \\
\hline & Sum & 25 & 25 & 29 & 25 & 36 & 41 & 45 & 46 \\
\hline & $\%$ recovery & 106 & 106 & 136 & 91 & 104 & 89 & 95 & 99 \\
\hline \multirow[t]{7}{*}{$\mathrm{Cd}$} & Exchangeable & 0.1 & 0.1 & 0.1 & 0.1 & 0.1 & 0.1 & 0.1 & 0.1 \\
\hline & Carbonate & 0.2 & 0.2 & 0.2 & 0.2 & 0.2 & 0.2 & 0.3 & 0.2 \\
\hline & Reducible & 0.4 & 0.4 & 0.3 & 0.4 & 0.4 & 0.4 & 0.4 & 0.3 \\
\hline & Oxidizable & 0.1 & 0.1 & 0.1 & 0.1 & 0.1 & 0.1 & 0.1 & 0.1 \\
\hline & Residual & 0.8 & 0.5 & 0.5 & 0.4 & 0.6 & 0.5 & 0.6 & 0.6 \\
\hline & Sum & 1.6 & 1.2 & 1.2 & 1.1 & 1.3 & 1.3 & 1.5 & 1.3 \\
\hline & $\%$ recovery & 89 & 92 & 96 & 102 & 88 & 97 & 84 & 94 \\
\hline \multirow[t]{7}{*}{$\mathrm{Cr}$} & Exchangeable & 0.1 & 0.2 & 0.2 & 0.2 & 0.1 & 0.1 & 0.2 & 0.2 \\
\hline & Carbonate & 0.1 & 0.1 & 0.1 & 0.1 & 0.1 & 0.1 & 0.1 & 0.1 \\
\hline & Reducible & 1.4 & 1.6 & 1.9 & 1.6 & 2.1 & 2.9 & 2.7 & 4.7 \\
\hline & Oxidizable & 0.6 & 0.7 & 0.7 & 0.4 & 0.9 & 0.8 & 0.7 & 0.5 \\
\hline & Residual & 44 & 47 & 54 & 47 & 59 & 64 & 52 & 58 \\
\hline & Sum & 47 & 49 & 57 & 50 & 62 & 68 & 56 & 63 \\
\hline & \% recovery & 104 & 102 & 114 & 102 & 98 & 105 & 104 & 104 \\
\hline \multirow[t]{7}{*}{$\mathrm{Ni}$} & Exchangeable & 0.2 & 0.1 & 0.1 & 0.1 & 0.2 & 0.2 & 0.1 & 0.1 \\
\hline & Carbonate & 0.1 & 0.2 & 0.3 & 0.4 & 0.4 & 0.4 & 0.4 & 0.4 \\
\hline & Reducible & 3.5 & 4.1 & 4.4 & 4.3 & 6.8 & 6.6 & 4.5 & 4.4 \\
\hline & Oxidizable & 0.3 & 0.3 & 0.4 & 0.4 & 0.3 & 0.2 & 0.2 & 0.2 \\
\hline & Residual & 23 & 23 & 19 & 23 & 41 & 46 & 28 & 32 \\
\hline & Sum & 27 & 27 & 25 & 29 & 49 & 53 & 33 & 37 \\
\hline & $\%$ recovery & 98 & 120 & 107 & 120 & 103 & 114 & 103 & 125 \\
\hline
\end{tabular}


were not high, being only slightly higher than those found natural soils, the origin of $\mathrm{Ni}$ and $\mathrm{Cr}$ can be associated with the materials used during the construction of the industrial complex (building, roads etc.).

It was found from the concentration pattern of seven metals that the importance of identify the more impacted areas is crucial to develop remediation or monitoring strategies, since some metals, such as $\mathrm{Cu}, \mathrm{Ni}$ and $\mathrm{Cr}$, affected mainly small areas easily delimited where specific action can be carried out, e.g. waste discharge control. In contrast, the impact of other metals such as $\mathrm{Pb}, \mathrm{Zn}$ and $\mathrm{Cd}$ is distributed in a wider area and therefore other strategies must be carried out, such as the implementation of phytotechnologies.

\subsection{Behaviour of metals in industrial soils}

For an appropriate assessment of contaminated areas is necessary to know the behaviour of metals which helps to design sustainable actions
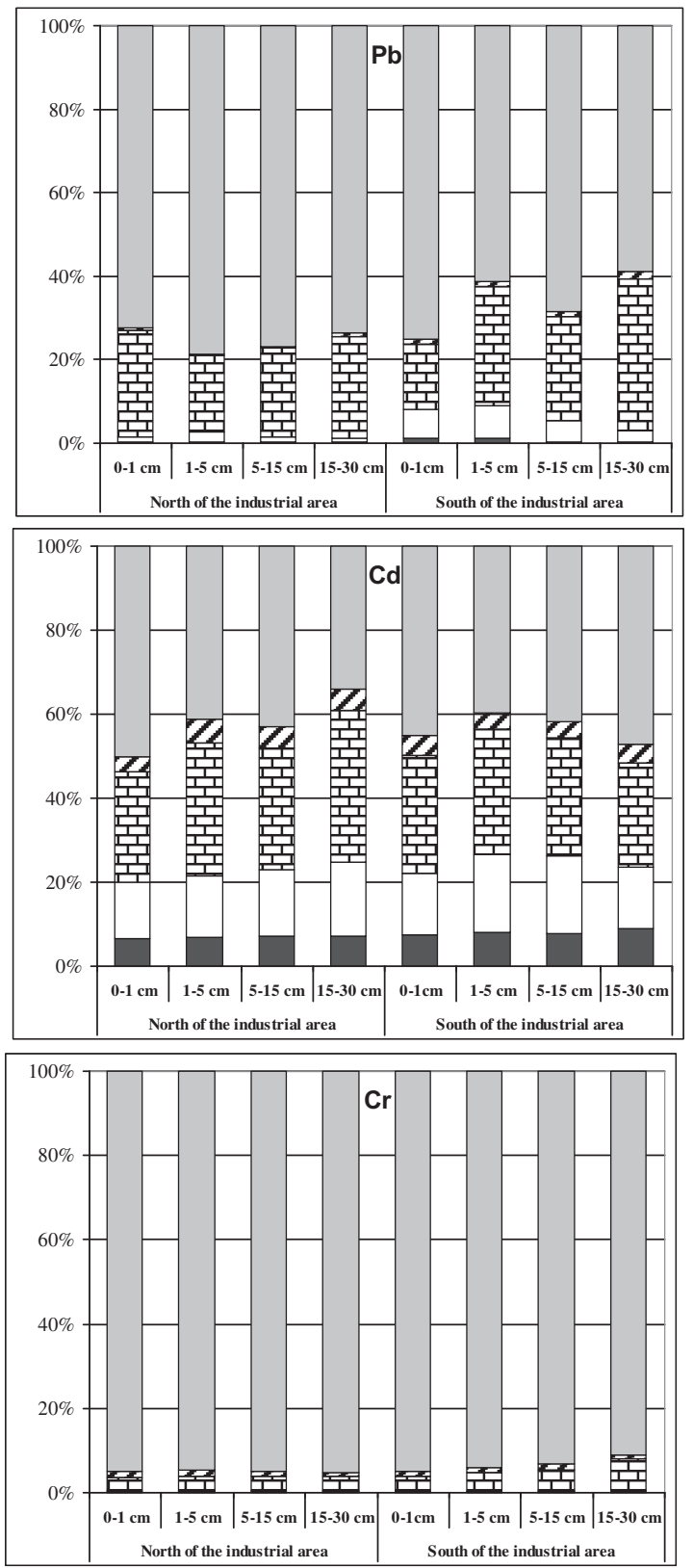

for reducing the environmental and human health risks. In addition, it has been demonstrated that metals behaviour in soils depends of many factors, such as soil properties and characteristics, source of metals, metal distribution in soil constituents, anthropogenic activities, etc. (Abollino et al., 2002; Micó et al., 2006; Wu et al., 2011). Because of the complex mechanisms and processes occurring in the soil and in order to reach a thorough knowledge on metal behaviour is necessary to use advanced analytical and statistical methods, such as metals sequential extraction and multivariable analysis (Nogueirol et al., 2010; Acosta et al., 2014; Hossain et al., 2015; Gasparatos et al., 2015; Schneider et al., 2016).

Table 3 shows the geochemical characterization of samples collected from soil profiles. Physicochemical properties such as $\mathrm{pH}, \mathrm{EC}$ and carbonates were similar between both profiles and among depths, being alkaline, saline and with high percentage of carbonates. In contrast, organic carbon contents and CEC showed differences among profiles and
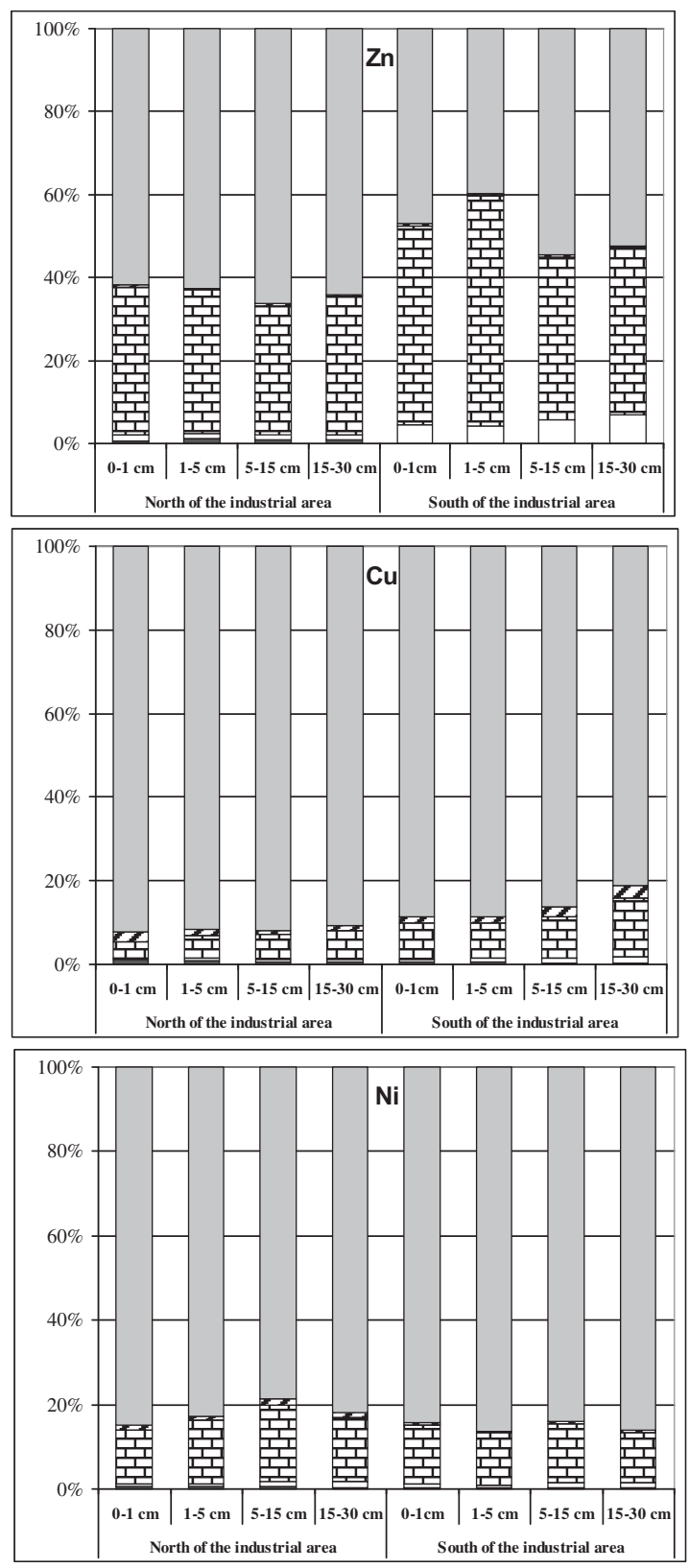

Exchangeables

$\square$ Carbonates

田 Reducible

$\square$ Oxidizable

Residuals

Fig. 3. Chemical partitioning of metals in soil profiles. 
depths being higher in surface soil, in addition, the profile located in the northwest area had higher organic carbon content and CEC than the profile located in the southwest. Total concentrations of $\mathrm{Pb}, \mathrm{Zn}, \mathrm{Cu}, \mathrm{Cr}$ and Ni were higher in the southwest profile, while total $\mathrm{Cd}$ was similar in both profiles. The DTPA concentrations of $\mathrm{Pb}$ and $\mathrm{Zn}$ were higher in the southwest profile, while $\mathrm{Cu}, \mathrm{Cd}, \mathrm{Cr}$ and $\mathrm{Ni}$ concentrations were similar between both profiles. However, the DTPA concentrations for all metals were similar between depths.

Concentration of each metal in each fraction from chemical speciation is reported in Table 4, while the percentage of contribution of each fraction to the total concentration for a specific metal is shown in Fig. 3. The results from principal component analysis are showed in Table 5. The highest concentration of $\mathrm{Pb}$ in the industrial soils was observed in the residual phase for both profiles and for the different depths. However, when the total Pb concentration increased (northwest profile), $\mathrm{Pb}$ was more associated to labile phases, mainly bound to Fe-Mn oxides and carbonate. This is supported by the results from PCA (Table 5) where Pb total concentration and all phases, except for exchangeable $\mathrm{Pb}$, were associated to Factor 1 . These results suggest that an increase in the anthropogenic $\mathrm{Pb}$ is proportional to $\mathrm{Pb}$ associated to the reducible and carbonates phases, especially observed in the northwest profile, and therefore a higher risk of mobility occurs in this area.

Zn concentration was mainly associated to the residual phase in all samples, although the fraction bound to the reducible phase was high (Table 4, Fig. 3), even higher than the value reported for Pb which had

Table 5

Varimax-rotated factor matrix for industrial soils.

\begin{tabular}{|c|c|c|c|c|}
\hline & 1 & 2 & 3 & Communalities \\
\hline $\mathrm{pH}$ & 0.00 & -0.09 & -0.52 & 0.58 \\
\hline Electrical conductivity & -0.53 & 0.80 & 0.14 & 0.93 \\
\hline Carbonates & -0.22 & -0.93 & 0.11 & 0.93 \\
\hline Organic carbon & -0.19 & -0.32 & 0.87 & 0.89 \\
\hline Cation exchangeable cationic & -0.23 & -0.39 & 0.83 & 0.90 \\
\hline $\mathrm{Pb}$ - exchangeable & -0.20 & -0.92 & -0.07 & 0.90 \\
\hline $\mathrm{Pb}$ - bound to carbonates & 0.85 & 0.50 & 0.00 & 0.97 \\
\hline $\mathrm{Pb}$ - bound to Fe and Mn oxides & 0.97 & 0.21 & 0.04 & 0.99 \\
\hline $\mathrm{Pb}$ - bound to organic matter & 0.92 & 0.28 & 0.09 & 0.93 \\
\hline $\mathrm{Pb}$ - residual & 0.91 & 0.33 & 0.03 & 0.94 \\
\hline $\mathrm{Pb}-$ total & 0.97 & 0.24 & 0.00 & 1.00 \\
\hline $\mathrm{Zn}$ - exchangeable & 0.98 & -0.11 & 0.01 & 0.98 \\
\hline $\mathrm{Zn}$ - bound to carbonates & 0.99 & 0.11 & 0.03 & 0.99 \\
\hline $\mathrm{Zn}$ - bound to Fe and Mn oxides & 0.65 & 0.70 & 0.03 & 0.92 \\
\hline $\mathrm{Zn}$ - bound to organic matter & 0.76 & 0.60 & -0.06 & 0.95 \\
\hline $\mathrm{Zn}$ - residual & 0.92 & -0.02 & 0.01 & 0.85 \\
\hline $\mathrm{Zn}$ - total & 0.91 & 0.24 & 0.06 & 0.89 \\
\hline $\mathrm{Cu}$ - exchangeable & 0.38 & -0.12 & 0.65 & 0.58 \\
\hline $\mathrm{Cu}$ - bound to carbonates & 0.11 & 0.96 & -0.17 & 0.96 \\
\hline $\mathrm{Cu}$ - bound to $\mathrm{Fe}$ and $\mathrm{Mn}$ oxides & 0.23 & 0.93 & -0.25 & 0.98 \\
\hline $\mathrm{Cu}$ - bound to organic matter & 0.10 & 0.97 & 0.05 & 0.95 \\
\hline $\mathrm{Cu}$ - residual & 0.47 & 0.85 & -0.05 & 0.95 \\
\hline $\mathrm{Cu}$ - total & 0.44 & 0.86 & -0.04 & 0.92 \\
\hline $\mathrm{Cd}$ - exchangeable & 0.17 & 0.87 & 0.42 & 0.96 \\
\hline $\mathrm{Cd}$ - bound to carbonates & 0.23 & -0.56 & 0.38 & 0.61 \\
\hline $\mathrm{Cd}$ - bound to Fe and Mn oxides & -0.06 & -0.07 & 0.60 & 0.66 \\
\hline Cd - bound to organic matter & -0.10 & -0.27 & -0.62 & 0.59 \\
\hline $\mathrm{Cd}$ - residual & 0.01 & 0.35 & 0.80 & 0.77 \\
\hline $\mathrm{Cd}$ - total & 0.11 & 0.40 & 0.77 & 0.77 \\
\hline $\mathrm{Cr}$ - exchangeable & -0.43 & 0.81 & -0.30 & 0.93 \\
\hline $\mathrm{Cr}$ - bound to carbonates & 0.47 & 0.56 & -0.45 & 0.73 \\
\hline $\mathrm{Cr}$ - bound to $\mathrm{Fe}$ and $\mathrm{Mn}$ oxides & 0.14 & 0.89 & -0.26 & 0.87 \\
\hline $\mathrm{Cr}$ - bound to organic matter & 0.81 & -0.17 & 0.23 & 0.74 \\
\hline $\mathrm{Cr}$ - residual & 0.75 & 0.38 & -0.31 & 0.81 \\
\hline $\mathrm{Cr}-$ total & 0.82 & 0.45 & -0.27 & 0.94 \\
\hline $\mathrm{Ni}$ - exchangeable & 0.26 & -0.19 & 0.93 & 0.97 \\
\hline $\mathrm{Ni}$ - bound to carbonates & 0.45 & 0.39 & -0.72 & 0.87 \\
\hline $\mathrm{Ni}$ - bound to Fe and Mn oxides & 0.97 & 0.01 & -0.20 & 0.98 \\
\hline $\mathrm{Ni}$ - bound to organic matter & -0.43 & -0.72 & -0.11 & 0.72 \\
\hline $\mathrm{Ni}$ - residual & 0.91 & 0.27 & 0.01 & 0.90 \\
\hline $\mathrm{Ni}$ - total & 0.97 & 0.16 & 0.15 & 0.98 \\
\hline$\%$ of variance & 38.0 & 30.9 & 15.5 & \\
\hline
\end{tabular}

higher total concentration. In addition, and similarly to $\mathrm{Pb}$, the profile collected from the southwest area, with higher $\mathrm{Zn}$ concentrations, showed an important fraction of $\mathrm{Zn}$ bound to carbonates. PCA showed that all phases of $\mathrm{Zn}$, except for $\mathrm{Zn}$ bound to Fe and Mn oxides, were associated to its total concentration in Factor 1 (Table 5). This indicates that $\mathrm{Zn}$ total concentration controls the behaviour of this element in soils, and it can be more easily mobilized from soils affected by anthropogenic pollution, since an increase of total concentration will likely promote higher concentrations of exchangeable $\mathrm{Zn}$ and $\mathrm{Zn}$ bound to carbonate.

Chemical partitioning of $\mathrm{Cd}$ was dominated by the residual and reducible phases, although a significant percentage of $\mathrm{Cd}$ was bound to the carbonate and exchangeable phases (Fig. 3). PCA showed that the concentration of $\mathrm{Cd}$ from the most labile fractions (exchangeable and bound to carbonates) were mainly affected by EC and carbonates content (Factor 2), while the other fractions were affected by $\mathrm{pH}, \mathrm{OC}, \mathrm{CEC}$ and its total concentration (Factor 3 ) (Table 5). These results suggest that $\mathrm{Cd}$ can become easily mobilized under $\mathrm{pH}$ and salinity variations, and therefore a higher environmental risk is expected for this metal than for the previous ones (Osakwe, 2013).

$\mathrm{Cu}$ was mainly associated to the residual phase, although a low but significant content was bound to the reducible and oxidizable phases (Table 4 and Fig. 3). The behaviour of $\mathrm{Cu}$ is mainly dominated by the carbonate content, EC and its total concentration, as reported in Factor 2 (Table 5) where all phases, except for soluble $\mathrm{Cu}$, were included. However, soluble Cu was correlated to $\mathrm{OC}$ and $\mathrm{pH}$ in Factor 3. These observations indicate that $\mathrm{Cu}$ can be mobilized after organic matter mineralization, as reported by Ma and Rao (1997). However, a high environmental risk is not expected due to the low organic matter content and the low concentration of this metal in the studied soils.

$\mathrm{Cr}$ and Ni were mainly bound to the residual phase in all samples, with very low concentration in the rest of the chemical phases (Table 4 and Fig. 3). These results suggest that $\mathrm{Cr}$ and $\mathrm{Ni}$ came from other sources different to current industrial activities, such as lithological materials (Shi et al., 2008; Li et al., 2013a) or other materials used for constructing the industrial complex as they are incorporated in the lattice of minerals. PCA showed that the concentration of $\mathrm{Cr}$ from exchangeable, bound to carbonates and bound to Fe and Mn oxides were mainly affected by EC and carbonates content (Factor 2), while the other fractions were associated in Factor 1 (Table 5). In contrast, most labile fractions of $\mathrm{Ni}$ (exchangeable and bound to carbonates) were mainly affected by variation of $\mathrm{pH}, \mathrm{OC}$ and CEC (Factor 3 ), while Ni bound to Fe and Mn oxides and residual fraction are associated to its total concentration.

These results suggest that the sources of metals and the soil properties ( $\mathrm{pH}, \mathrm{CEC}$ and EC) are important in the speciation of the studied metals in contaminated soils. Additionally, the soil composition (organic carbon and carbonates content) will determine the form of metals that dominates in the soil fractions.

\section{Conclusions}

The studied industrial soils were moderately contaminated by Zn, $\mathrm{Pb}, \mathrm{Cr}, \mathrm{Cu}$ and $\mathrm{Ni}$, with a moderate ecological risk, and therefore some remediation actions should be carried out in order to reduce the risk for human health and the environment, techniques as phytoremediation or physical-chemical metal extraction could be used to reduce total metal content in soils, although further studies are necessaries for an adequate selection. Spatial distribution maps showed two different areas, the southeast area with the highest concentration of metals and the northwest area where moderate levels of metals were found. Metals associated to industrial activity, such as $\mathrm{Pb}$ and $\mathrm{Zn}$, showed a more disperse distribution into the industrial complex.

Results suggested that when $\mathrm{Pb}$ and $\mathrm{Zn}$ come from anthropogenic sources, they are mainly associated to the most labile phases; in contrast, when these metals come from geological sources, they are mainly bound to the most immobile phases. $\mathrm{Cu}, \mathrm{Cr}$ and $\mathrm{Ni}$ were mainly 
associated to the residual phase, with very low concentrations bound to Fe-Mn oxides, and with insignificant levels bound to the most labile phases. Cd was the most mobile metal since a high percentage of its concentration was associated to the exchangeable and carbonates phases. Therefore, $\mathrm{Pb}, \mathrm{Zn}$ and $\mathrm{Cd}$ pose higher health and environmental risk because of their mobilization capacity, and should be monitored.

The optimal remediation techniques for dealing with metals contaminated soil will depend on the metal speciation, since this will influence the efficiency of these techniques. Therefore, a comprehensive and detailed understanding of the metals behaviour is critical for developing and evaluating remediation strategies at a site, which can be carried out through advances analytical, statistical and geostatistical methods such as sequential extraction, multivariable analysis and mapping.

\section{Acknowledgments}

The financial support to conduct this study was provided by the Fundación Séneca of Comunidad Autónoma de Murcia (15380/PI/10) (Spain).

\section{References}

Abollino, O., Aceto, M., Malandrino, M., Mentasti, E., Sarzanini, C., Barberis, R., 2002. Distribution and mobility of heavy metals in contaminated sites. Chemometric investigation of pollutant profiles. Environ. Pollut. 119, 177-193.

Acosta, J.A., Faz, A., Martínez-Martínez, S., Zornoza, R., Carmona, D.M., Kabas, S., 2011. Multivariate statistical and GIS-based approach to evaluate heavy metals behavior in mine sites for future reclamation. J. Geochem. Explor. 109, 8-17.

Acosta, J.A., Faz, A., Kalbitz, K., Jansen, B., Martínez-Martínez, S., 2014. Partitioning of heavy metals over different chemical fraction in street dust of Murcia (Spain) as a basis for risk assessment. J. Geochem. Explor. 144, 298-305.

Acosta, J.A., Gabarron, M., Faz, A., Martinez-Martinez, S., Zornoza, R., Arocena, J.M., 2015. Influence of population density on the concentration and speciation of metals in the soil and street dust from urban areas. Chemosphere 134, 328-337.

Aelion, C.M., Davis, H.T., McDermott, S., Lawson, A.B., 2009. Soil metal concentrations and toxicity: associations with distances to industrial facilities and implications for human health. Sci. Total Environ. 407, 2216-2223.

Al-Khashman, O.A., Shawabkeh, R.A., 2006. Metals distribution in soils around the cement factory in southern Jordan. Environ. Pollut. 140, 387-394.

Andrades, M., 1996. Prácticas de Edafología y Climatología (pp. 14-16). In: Universidad de la Rioja (Ed.), Logroño. La Rioja, España.

Buhiyan, M.A.H., Parvez, L., Islam, M.A., Dampare, S.B., Suzuki, S., 2010. Heavy metal pollution of coal mine-affected agricultural soils in the northern part of Bangladesh. J. Hazard. Mater. 173, 384-392.

Burgos, P., Madejon, E., Perez-de-Mora, A., Cabrera, F., 2006. Spatial variability of the chemical characteristics of a trace-element-contaminated soil before and after remediation. Geoderma 130, 157-175.

Burrough, P.A., McDonnell, R.A., 1998. Creating continuous surfaces from point data. In: Burrough, P.A., Goodchild, M.F., McDonnell, R.A., Switzer, P., Worboys, M. (Eds.), Principles of Geographic Information Systems. Oxford University Press, Oxford.

Chen, T., Liu, X., Li, X., Zhao, K., Zhang, J., Xu, J., Shi, J., Dahlgreen, R.A., 2009. Heavy metal sources identification and sampling uncertainty analysis in a field-scale vegetable soil of Hangzhou, China. Environ. Pollut. 157, 1003-1010.

Christoforidis, A., Stamatis, N., 2009. Heavy metal contamination in street dust and roadside soil along the major national road in Kavala's region, Greece. Geoderma 151, 257-263.

Ernst, W.H.O., 1996. Bioavailability of heavy metals and decontamination of soils by plants. Appl. Geochem. 11, 163-167.

FIMRT, 2010. Certificate Reference Material Catalogue. Federal Institute for Material Research and Testing, Germany.

Fakayode, S.O., Onianwa, P.C., 2002. Heavy metal contamination of soil, and bioaccumulation in Guinea grass (Panicumacium maximum) around Ikeja Industrial Estate, Lagos, Nigeria. Environ. Geol. 43, 145-150.

Gasparatos, D., Mavromati, G., Kotsovilis, P., Massas, I., 2015. Fractionation of heavy metals and evaluation of the environmental risk for the alkaline soils of the Thriassio plain: a residential, agricultural, and industrial area in Greece. Environ. Earth Sci. 74, 1099-1108.

Govil, P.K., Sorlie, J.E., Murthy, N.N., Sujatha, D., Reddy, G.L.N., Rudolph-Lund, K., Krishna, A.K., Rama Mohan, K., 2008. Soil contamination of heavy metals in the Katedan Industrial Development Area, Hyderabad, India. Environ. Monit. Assess. 140, 313-323.

Gowd, S.S., Reddy, M.R., Govil, P.K., 2010. Assessment of heavy metal contamination in soils at Jajmau (Kanpur) and Unnao industrial areas of the Ganga Plain, Uttar Pradesh, India. J. Hazard. Mater. 174, 113-121.

Guillén, M.T., Delgado, J., Albanese, S., Nieto, J.M., Lima, A., De Vivo, B., 2012. Heavy metals fractionation and multivariate statistical techniques to evaluate the environmental risk in soils of Huelva township (SW Iberian Peninsula). J. Geochem. Explor. 119$120,32-43$.

Hakanson, L., 1980. An Ecological risk index for aquatic pollution control: a sedimentological approach. Water Res. 14, 975-1001.
Han, D., Zhang, X., Tomar, V., Li, Q., Wen, D., Liang, W., 2009. Effects of heavy metal pollution of highway origin on soil nematode guilds in North Shenyang, China. J. Environ. Sci. 21, 193-198.

Hossain, M.A., Ali, N.M., Islam, M.S., Hossain, H.M.Z., 2015. Spatial distribution and source apportionment of heavy metals in soils of Gebeng industrial city, Malaysia. Environ. Earth Sci. 73, 115-126.

IGME, 1976. Geological Map of Spain, E. 1:50000. Murcia. Servicio de Publicaciones del Ministerio de Industria, Madrid Memoria (in Spanish).

Imperato, M., Adamo, P., Naimo, D., Arienzo, M., Stanzione, D., Violante, P., 2003. Spatial distribution of heavy metals in urban soils of Naples City (Italy). Environ. Pollut. 124, 247-256.

Jean, L., Bordas, F., Bollinger, J.-C., 2007. Chromium and nickel mobilization from a contaminated soil using chelants. Environ. Pollut. 147, 729-736.

Krishna, A.K., Govil, P.K., 2008. Assessment of heavy metal contamination in soils around Manali industrial area, Chennai, Southern India. Environ. Geol. 54 (7), 1465-1472.

Kumar, M., Furumai, H., Kurisu, F., Kasuga, I., 2013. Tracing source and distribution of heavy metals in road dust, soil and soakaway sediment through speciation and isotopic fingerprinting. Geoderma 211-212, 8-17.

Lee, C.S.-L., Li, X., Shi, W., Cheung, S.C.-N., Thornton, I., 2006. Metal contamination in urban, suburban, and country park soils of Hong Kong: a study based on GIS and multivariate statistics. Sci. Total Environ. 356, 45-61.

Li, X., Coles, B.J., Ramsey, M.H., Thornton, I., 1995. Sequential extraction of soils for multielement analysis by ICP-AES. Chem. Geol. 124, 109-123.

Li, H., Qian, X., Hu, W., Wang, Y., Gao, H., 2013a. Chemical speciation and human health risk of trace metals in urban street dusts from a metropolitan city, Nanjing, SE China. Sci. Total Environ. 456-457, 212-221.

Li, X., Liu, L., Wang, Y., Luo, G., Chen, X., Yang, X., Hall, M.H., Guo, R., Wang, H., Cui, J., He, X. 2013b. Heavy metal contamination of urban soil in an old industrial city (Shenyang) in Northeast China. Geoderma 192, 50-58.

Lin, Q., Liu, E.F., Zhang, E.L., Li, K., Shen, J., 2016. Spatial distribution, contamination and ecological risk assessment of heavy metals in surface sediments of Erhai Lake, a large eutrophic plateau lake in southwest China. Catena 145, 193-203.

Linsay, W.L., Norvell, W.A., 1978. Development of a DTPA soil test for zinc, iron, manganese and copper. Soil Sci. Soc. Am. J. 42, 42-428.

Loska, K., Wiechula, D., Korus, I., 2004. Metal contamination of farming soils affected by industry. Environ. Int. 30, 159-165.

Lu, A., Wang, J., Qin, X., Wang, K., Han, P., Zhang, S., 2012. Multivariate and geostatistical analyses of the spatial distribution and origin of heavy metals in the agricultural soils in Shunyi, Beijing, China. Sci. Total Environ. 425, 66-74.

Lu, X., Wu, X., Wang, Y., Chen, H., Gao, P., Fu, Y., 2014. Risk assessment of toxic metals in street dust from a medium-sized industrial city of China. Ecotoxicol. Environ. Saf. 106, 154-163.

Ma, L.Q., Rao, G.N., 1997. Chemical fractionation of cadmium, copper, nickel and zinc in contaminated soils. J. Environ. Qual. 26, 259-264.

Maas, S., Scheifler, R., Benslama, M., Crini, N., Lucot, E., Brahmia, Z., Benayacoub, S., Giradoux, P. 2010. Spatial distribution of heavy metal concentrations in urban, suburban and agricultural soils in a Mediterranean city of Algeria. Environ. Pollut. 158, 2294-2301.

Manta, D.S., Angelone, M., Bellanca, A., Neri, R., Sprovieri, M., 2002. Heavy metals in urban soils: a case study from the city of Palermo (Sicily), Italy. Sci. Total Environ. 300 229-243.

McNear, D.H., Chaney, R.L., Sparks, D.L., 2007. The effects of soil type and chemical treatment on nickel speciation in refinery enriched soils: a multi-technique investigation. Geochim. Cosmochim. Acta 71, 2190-2208.

Micó, C., Recatalá, L., Peris, M., Sánchez, J., 2006. Assessing heavy metal sources in agricultural soils of an European Mediterranean area by multivariate analysis. Chemosphere $65,863-872$.

Naji, A., Ismail, A., Ismail, A.R., 2010. Chemical speciation and contamination assessment of $\mathrm{Zn}$ and $\mathrm{Cd}$ by sequential extraction in surface sediment of Klang River, Malaysia. Microchem. J. 95, 285-292.

Nogueirol, R. C., Ferracciu-Alleoni, L. R., Nachtigall, G.R., Wellington de Melo, G. (2010). Sequential extraction and availability of copper in $\mathrm{Cu}$ fungicide-amended vineyard soils from Southern Brazil. J. Hazard. Mater. 181 (2010) 931-937.

Norusis, M.J., 1993. SPSS for Windows Base System User's Guide Release 6.0. SPSS Inc.

Ordoñez, A., Loredo, J., De Miguel, E., Charlesworth, S., 2003. Distribution of heavy metals in the street dusts and soils of an industrial city in northern Spain. Arch. Environ. Contam. Toxicol. 44, 160-170.

Osakwe, S.A., 2013. Chemical partitioning of iron, cadmium, nickel and chromium in contaminated soils of south-eastern Nigeria. Chem. Speciat. Bioavailab. 25, 71-78.

Pastor, J., Aparicio, A.M., Gutiérrez-Maroto, A., Hernández, A.J., 2007. Effects of two chelating agents (EDTA and DTPA) on the autochthonous vegetation of a soil polluted with $\mathrm{Cu}, \mathrm{Zn}$ and Cd. Sci. Total Environ. 378, 114-118.

Pen-Mouratov, S., Shukurov, N., Steinberger, Y., 2008. Influence of industrial heavy metal pollution on soil free-living nematode population. Environ. Pollut. 152, 172-183.

Rauret, G., 1998. Extraction procedures for the determination of heavy metals in contaminated soil and sediment. Talanta 46, 449-455.

Ravera, M., Ciccarelli, C., Gastaldi, D., Rinaudo, C., Castelli, C., Osella, D., 2006. An experiment in the electrokinetic removal of copper from soil contaminated by the brass industry. Chemosphere 63, 950-955.

Risser, J.A., Baker, D.E., 1990. Testing soils for toxic metals. In: Westerman, R.L. (Ed.), Soil Testing and Plant Analysis, third ed. Soil Sci. Soc. Amer. Spec. Publ., 3 (Madison, WI, 275-298 pp.).

Rodríguez-Martín, J.A., Arias, M.L., Grau-Corbí, J.M., 2006. Heavy metals contents in agricultural topsoils in the Ebro basin (Spain). Application of the multivariate geoestatistical methods to study spatial variations. Environ. Pollut. 144, 1001-1012.

Saby, N.P.A., Thioulouse, J., Jolivet, C.C., Ratié, C., Boulonne, L., Bispo, A., Arrouays, D., 2009 Multivariate analysis of the spatial patterns of 8 trace elements using the French soil monitoring network data. Sci. Total Environ. 407, 5644-5652. 
Saeedi, M., Li, L.Y., Salmanzadeh, M., 2012. Heavy metals and polycyclic aromatic hydrocarbons: pollution and ecological risk assessment in street dust of Tehran. J. Hazard. Mater. 227-228, 9-17.

Schneider, A.R., Cances, B., Ponthieu, M., Sobanska, S., Benedetti, M.F., Pourret, O., Conreux A., Calandra, I., Martinet, B., Morvan, X., Gommeaux, M., Marin, B., 2016. Sci. Total Environ. 568, 155-163.

Sekhar, K.C., Chary, N.S., Kamala, C.T., Vairamani, M., Anjaneyulu, Y., Balaram, V., Sorlie J.E., 2006. Environmental risk assessment studies of heavy metal contamination in the industrial area of Kattedan, India-a case study. Hum. Ecol. Risk. Assess. 12 (2), 408-422.

Shao, X., Huang, B., Zhao, Y., Sun, W., Gu, Z., Qian, W., 2014. Impacts of human activities and sampling strategies on soil heavy metal distribution in a rapidly developing region of China. Ecotoxicol. Environ. Saf. 104, 1-8.

Shi, G., Chen, Z., Xu, S., Zhang, J., Wang, L., Bi, C., Teng, J., 2008. Potentially toxic metal contamination of urban soils and roadside dust in Shanghai, China. Environ. Pollut. 156 251-260.

Soil Survey Staff, 2004. Soil Survey Laboratory Methods Manual. Version No. 4.0. USDA NRCS. Soil Survey Investigations Report No. 42. U.S. Govt. Print. Office, Washington (407 pp).

Sun, Y., Zhou, Q., Xie, X., Liu, R., 2010. Spatial, sources and risk assessment of heavy meta contamination of urban soils in typical regions of Shenyang, China. J. Hazard. Mater. $174,455-462$.

Tessier, A., Campbell, P.G.C., Blsson, M., 1979. Sequential extraction procedure for the speciation of particulate trace metals. Anal. Chem. 51, 844-851.
Varol, M., 2011. Assessment of heavy metal contamination in sediments of the Tigris River (Turkey) using pollution indices and multivariate statistical techniques. J. Hazard. Mater. 195, 355-364.

WRB, 2014. International Soil Classification System for Naming Soils and Creating Legends for Soil Maps. World Soil Resources Reports 106. Food and Agriculture Organization of the United Nations.

Wu, S., Zhou, S., Li, X., 2011. Determining the anthropogenic contribution of heavy metal accumulations around a typical industrial town: Xushe, China. J. Geochem. Explor. 110, 92-97.

Xiao, Q., Zong, Y.-T., Lu, S.-G., 2015. Assessment of heavy metal pollution and human health risk in urban soils of steel industrial city (Anshan), Liaoning, Northeast China. Ecotoxicol. Environ. Saf. 120, 377-385.

Yaylali-Abanuz, G., 2011. Heavy metal contamination of surface soil around Gebze industrial area, Turkey. Microchem. J. 99, 82-92.

Yuan, C.-G. Shi, J.-B., He, B. Liu, J.-F., Liang, L.-N., Jiang, G.-B., 2004 Speciation of heavy metals in marine sediments from the East China Sea by ICP-MS with sequential extraction. Environ. Int. 30, 769-783.

Yuan, G.L., Sun, T.H., Han, P., Li, J., Lang, X.X., 2014. Source identification and ecological risk assessment of heavy metals in topsoil using environmental geochemical mapping: typical urban renewal area in Beijing, China. J. Geochem. Explor. 136, 40-47.

Zhang, W.-G., Feng, H., Chang, J.-N., Qu, J.-G., Xie, H.-X., Yu, L.-Z., 2009. Heavy metal contamination in surface sediments of Yangtze River intertidal zone: an assessment from different indexes. Environ. Pollut. 157, 1533-1543. 